УДК 338.439:332

I. С. Крамаренко,

к.е.н., дочент, декан факультету права та сочіально-освітніх технологій,

Миколаївський міжрегіональний інститут розвитку людини Університету "Україна"

ORCID ID: 0000-0002-0417-0918

DOI: $10.32702 / 2306-6814.2019 .20 .5$

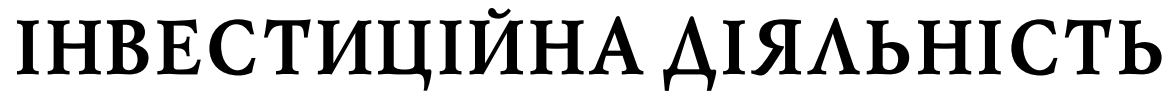 ПІАПРИЄМСТВ УКРАЇНИ: РЕГІОНААЬНИЙ ACחEKT
}

\author{
I. Kramarenko, \\ $\mathrm{PhD}$ in Economics Associate Professor, Dean of the Faculty of Law and Social and Information Technologies, \\ Mykolaiv Interregional Institute of Human Development of the "Ukraine" University
}

\section{INVESTMENT ACTIVITIES OF UKRAINE'S ENTERPRISES: REGIONAL ASPECT}

Устатті досліджено сучасний стан інвестиційної діяльності підприємств по регіонах України. Метою написання цього дослідження є необхідність аналізу сучасного стану інвестиційної діяльності підприємств на регіональному рівні. Основними завданнями дослідження є: аналіз обсягів освоєння інвестицій по регіонах України; формування системи напрямів покращення стану інвестиційної привабливості регіонів.

Проаналізовано змінудинаміки надходження капітальних інвестицій по регіонах, джерела їх формування та основні види активів капіталовкладень. Серед регіонів найбільше освоєння капітальних інвестицій належить тим, де значна кількість приватних підприємств, наявність промислово розвинутих підприємств металургійного, машинобудівного комплексів, хімічної промисловості та добре розвинута транспортна інфраструктура. Джерелами фінансування інвестиційної діяльності виступають власні кошти підприємств (70,8\%). Серед регіонів, де спостерігається найбільшадержавна підтримка, є Луганська $(37,1 \%$ від загальної суми освоєних інвестицій) та Чернівецька $(29,8 \%)$ області, це кошти державного та місцевого бюджетів.

Наведено головні причини регіональних диспропорцій капіталовкладень інвестицій. Серед яких: відсутність програм соціально-економічного розвитку в значної кількості територіальних громад (малих міст, селищ, сіл); відсутність регіональної системи маркетингу та промоції, недостатня розвиненість інфраструктури підтримки та системи інформаційного забезпечення інвестиційної діяльності; недостатній рівень кадрового потенціалу органів місцевого самоврядування та державної служби, задіяного в інвестиційних процесах на регіональномута місцевому рівнях; військовий конфлікт на сході України.

Розкрито головні напрями підвищення інвестиційної привабливості регіонів України, а саме: визначення стратегічних напрямів та пріоритетів інвестиційного розвиткуобласті; конкретизація пріоритетів інвестування, суб'єктів інвестування, розміру інвестицій та соціально-економічних наслідків для території; опрацювання досвіду, підготовка та надання органам державної влади пропозицій щодо вдосконалення нормативно-правової бази. Обгрунтовано необхідність розроблення дієвого механізму, форм та методів удосконалення регіональної політики у сфері залучення інвестицій, що базуватиметься на засадах поєднання ринкових і владних інструментів.

The article investigates the current state of investment activity of enterprises in the regions of Ukraine. Among the regions, the largest development of capital investments is those where a 
significant number of private enterprises, the presence of industrially developed enterprises of metallurgical, machine-building complexes, chemical industry and well-developed transport infrastructure.

The purpose of this study is to analyze the current state of investment activity of enterprises at the regional level. The main tasks of the research are: analysis of investment development volumes by regions of Ukraine; forming a system of directions for improving the investment attractiveness of regions. The sources of financing of investment activity are the own funds of enterprises (70.8\%). Among the regions with the highest state support are Lugansk $(37.1 \%$ of the total amount of investments invested) and Chernivtsi (29.8\%) of the region are state and local budgets.

Changes in the dynamics of capital inflows by regions, the sources of their formation and the main types of investment assets are analyzed. The main reasons for regional disproportions of investment investments are given. These include: lack of socio-economic development programs in a large number of territorial communities (small cities, towns, villages); lack of a regional marketing and promotion system, underdeveloped support infrastructure and information support system for investment activities; insufficient level of human resources of local self-government bodies and civil service involved in investment processes at regional and local levels; military conflict in eastern Ukraine.

The main directions of increasing the investment attractiveness of Ukrainian regions are revealed, namely: determination of strategic directions and priorities of investment development of the region; specification of investment priorities, entities, size of investment and socio-economic impact on the territory; elaboration of experience, preparation and submission of proposals for improvement of the legal base to the bodies of state power. The necessity to develop an effective mechanism, forms and methods for improving regional investment attracting policy based on a combination of market and government instruments is substantiated.

Ключові слоВа: інВестиції, капітальні інВестиції, інВестиційна діяльність, інВестиційна приВаблиВість, регіональні особлиВості інВестиційної приВаблиВості, осВоєння капітальних інВестицій.

Key words: investments, capital investments, investment activity, investment attractiveness, regional peculiarities of investment attractiveness, development of capital investments.

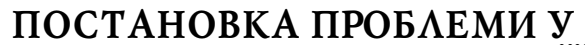
ЗАГА ЬЬНОМУ ВИГАЯАІ ТА ЇЇ ЗВ'ЯЗОК I3 ВАЖАИВИМИ НАУКОВИМИ ЧИ ПРАКТИЧНИМИ ЗАВААННЯМИ

Сучасні тенденції соціально-економічного розвитку держави, вимагають виваженої політики щодо інвестиційної привабливості підприємств. Адже успішна інвестиційна діяльність підприємств фрормує ефективну національну інвестиційну політику країни. Тому вивчення та аналіз сучасного стану інвестиційної діяльності підприємств на регіональному рівні, дозволить сорормувати дієвий механізм інвестиційної політики держави. Відповідно пошук проблем інвестиційних диспропорцій регіонів та напрями їх розв'язання в сучасних умовах господарювання $€$ досить актуальними.

\section{АНААIЗ ОСТ АНHIX АОС $А$ АЖЕНЬ І ПУБАІКАЦІЙ}

Дослідженню інвестиційної діяльності підприємств на їх регіональному рівні, інституціональним основам регіонального інвестування присвятили свої дослідження такі відомі економісти: В.М. Геєць, Н.О. Татаренко,
І.О. Бланк, Л.М. Борщ, В.С.Кравців, С.О. Іщук, Т.В. Кулініч, О.В. Збаращук та інші. Питання впливу інвестиційної діяльності на економічний розвиток територій досліджено в роботах таких економістів: Є.О. Бойко, Б.М. Данилишин, М.І. Долішній, О.В. Гаврилюк, З.В. Герасимчук, О.О. Другов, І.О. Іртищева, І.М. Котова, О.О. Лемішко, І.І. Лукінов, Ю.В. Макогон, Л.О. Петкова, В.І. Пила, В.М. Попов, В.Д. Попова, М.І. Стегней, Л.Є. Сімків, Д.В.Шиян. Однак сучасні глобалізаційні та інтеграційні процеси, світові тенденції соціально-економічного розвитку висувають нові вимоги до формування інвестиційної політики в Україні і регіональний аспект, у контексті імплементації європейського досвіду, $є$ визначальним.

\section{META CTATTI \\ (ПОСТАНОВКА ЗАВААННЯ)}

Метою статті $€$ дослідження сучасного стану інвестиційної діяльності підприємств на регіональному рівні. Основними завданнями дослідження є: аналіз рівня освоєння інвестицій по регіонах України; фрормування системи напрямів покращення стану інвестиційної привабливості регіонів. 


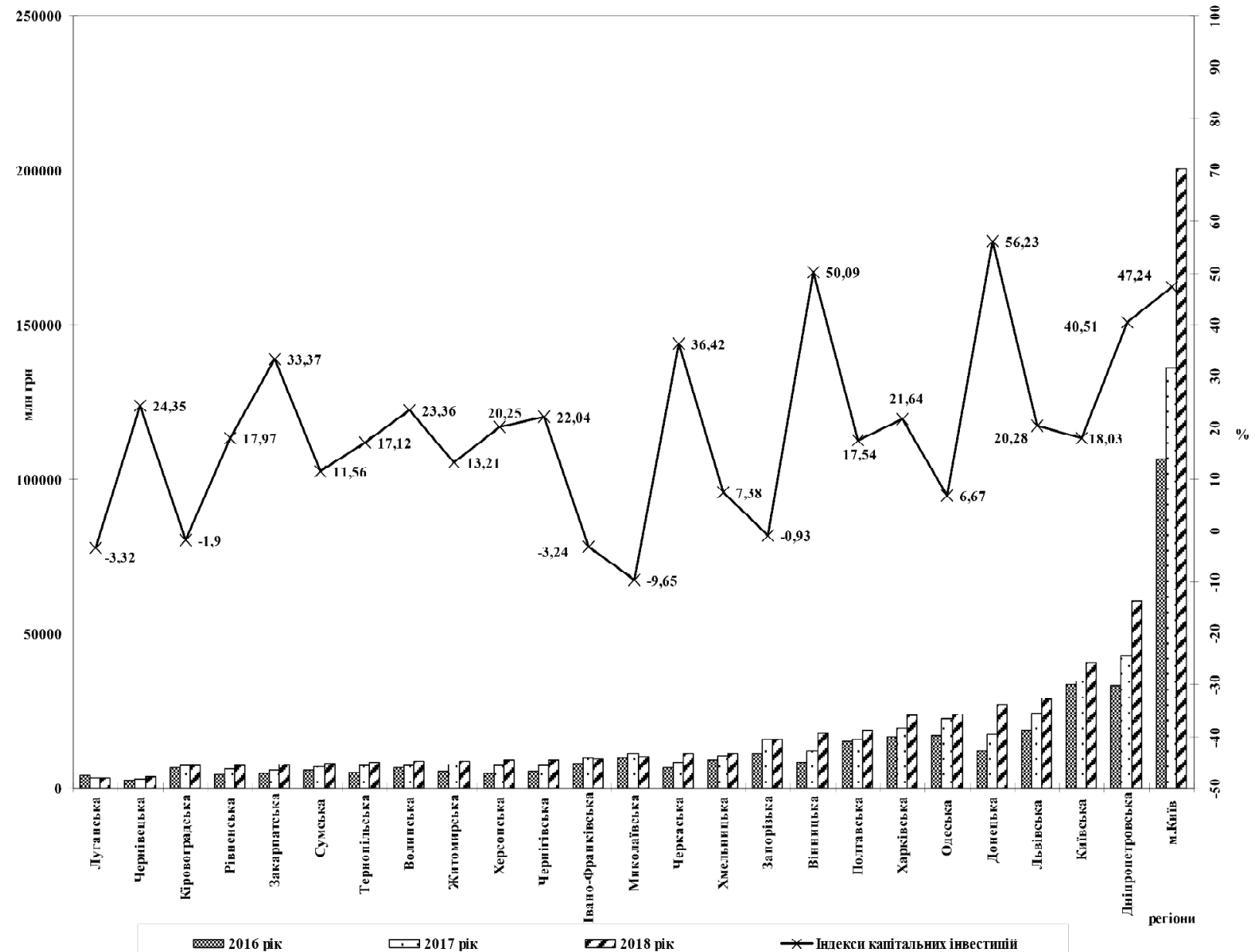

Рис. 1. Динаміка освоєння капітальних інвестицій по регіонах України за 2016-2017 роки Джерело: [1].

\section{ВИК ААА ОСНОВНОГО МАТЕРІААУ АОС АІАЖЕННЯ 3 ПОВНИМ ОБГРУНТУВАННЯМ ОТРИМАНИХ НАУКОВИХ РЕЗУАЬТАТІВ}

Інвестиційна діяльність підприємств відіграє значну роль, як у розвитку окремих територій, так і держави загалом. Позитивним в інвестиційній діяльності підприємств є стійке підвищення рівня її фрінансування. Так, за останні десять років найбільший обсяг капітальних інвестицій був у 2018 році - 578726,4 млн грн та у 2017 році 448461,5 млн грн, що в 2,1 та 1,6 рази більше за 2008 рік відповідно [1]. Головними фракторами, що сприяли підвищенню інвестиційної привабливості підприємств, це відновлення довіри інвесторів, збалансування макроекономічної рівноваги, прискорення структурних рефрорм у країні.

Залучення інвестицій в регіони України здійснюється у виді внесків рухомого й нерухомого майна (74\%), а також грошових внесків (близько $26 \%$ ), тобто ми бачимо, що інвестиції, які отримують підприємства, часто використовуються не на технічне переоснащення виробництва, а на реконструкцію й поновлення основного капіталу. У більшості випадків підприємства одержують інвестиції для підтримання існуючого виробництва без урахування конкурентоспроможності продукції, що, в свою чергу, призводить до зниження інтенсифрікації інвестиційного процесу. Зарубіжні інвестиції в регіони України здійснюються в різних формах, але основними $\epsilon$ державні та приватні. Перші здійснюються в національних інтересах, тому одержання прибутку не $є$ основною їх метою. Другі - у вигляді прямих, портфельних, кредитних та інших - проводяться власниками капіталу, які роблять довгострокові вкладення в галузі економіки. Порівнюючи величину прямих та портоельних інвестицій, визначають роль та значення іноземного капіталу в економіці країни. Прямі приватні інвестиції, на відміну від портфельних, дають право інвестору контролювати діяльність підприємств, у тому числі спільних. Портфельні ж інвестиції надходять у країну, як правило, шляхом продажу цінних паперів через міжнародні фрінансові інститути, фронди, експертні агентства, банки. У країну-реципієнт підприємницький капітал надходить також у формі позик, кредитів, грантів [2].

У регіонах України іноземні інвестиції освоюється теж нерівномірно. Найбільш пріоритетними, з точки зору аналізу інвестиційної політики, є Дніпропетровська, Київська, Львівська, Донецька, Одеська, Харківська, Полтавська області, а також м. Київ (рис. 1). Така регіональна структура розподілу пояснюється значним відсотком приватних підприємств, наявністю промислово розвинутих підприємств металургійного, машинобудівного комплексів, хімічної промисловості та добре розвинутою транспортною інфрраструктурою.

За даними рисунку, у 2018 році список по найбільшому використанню капітальних інвестицій очолює 
м. Київ - 200308,3 млн грн, далі Дніпропетровська 60288,6 млн грн, Київська - 40713,4 млн грн, Львівська 28995,5 млн грн, Донецька - 26979,4 млн грн, Одеська - 23787,8 млн грн, Харківська - 23551,3 млн грн, Полтавська - 18636,7 млн грн, Вінницька - 17626,5 млн грн, Запорізька - 15732,0 млн грн області. В кінці списку знаходяться Кіровоградська - 7181,5 млн грн, Чернівецька - 3720,6 млн грн і Луганська - 3219,3млн грн області. Однак, якщо розглядати зміну індексу капітальних інвестицій у 2018 року відносно 2017 року, необхідно зробити висновки, що найбільші зміни з освоє ння інвестиційних ресурсів відбулися у Донецькій більше за попередній рік на 56,23\%, Вінницькій на 50,09\%, місті Києву на 47,24\%, Дніпропетровській на 40,51\% області відповідно. Значне скорочення використання капітальних інвестицій спостерігаємо у Миколаївській $(-9,65 \%)$, Луганській $(-3,32 \%)$, Івано-Франківській $(-3,24 \%)$, Кіровоградській $(-1,9 \%)$, Запорізькій $(-0,93 \%)$ області.

Капітальні інвестиції в матеріальні та нематеріальні активи по регіонах за 2018 рік зосереджені майже однаково по всіх областях України, що в середньому становить 93,7\% у матеріальні та нематеріальні активи $6,3 \%$.

Джерелами фрінансування інвестиційної діяльності виступають власні кошти підприємств (70,8\%), до яких належить: амортизаційні відрахування 15,8\% від загальної суми інвестиційних ресурсів, кредити банків та позики - 7,8\%, кредити іноземних банків - 18,5\%. Держава незначними фінансовими ресурсами сприяє інвестиційній діяльності підприємств, адже питома вага коштів для освоєння капітальних інвестицій державного бюджету становить 3,9\% і місцевого 8,7\%. Серед регіонів де спостерігається найбільша державна підтримка $є$ Луганська (37,1\% від загальної суми інвестицій) та Чернівецька $(29,8 \%)$ області це кошти державного та місцевого бюджетів.

Структура інвестиційних ресурсів, що склалася в Україні останнім часом, не $є$ оптимальною. У нинішній ситуації інвестиції здебільшого здійснюються за рахунок коштів вітчизняних підприємств (72 \%). На другому місці $€$ кошти населення та кредити банківських установ. Завдяки фрінансовій децентралізації зросли інвестиції за рахунок коштів місцевих бюджетів. Суттєво зменшились іноземні інвестиції та зовсім незначним $\epsilon$ інвестування за рахунок коштів державного бюджету [3, с. 8].

За видами економічної діяльності пріоритетним напрямом для інвестування в Україні є промисловий сектор, частка якого у загальній структурі у 2018 році становила $34 \%$, другу позицію посідає аграрний сектор $(12,5 \%)$, третю - будівництво (9,9\%) [1].

Ми погоджуємося з думкою Сімківа Л.Є., що інвестиційні потоки обслуговують економічно розвинуті регіони України, лишаючи поза увагою менш розвинуті регіони, що потребують значного надходження іноземних інвестицій. Таке спрямування прямих іноземних інвестицій у регіональному розрізі не сприяє рівномірному соціально-економічному розвитку країни та посилює подальше збільшення регіональних диспропорцій. Задля усунення цих проблем повинна бути сорормована виважена та дієва державна інвестиційна політика, спря- мована на збільшення інвестиційної привабливості регіонів України [4, с. 434].

Основними причинами диспропорцій інвестиційної активності по регіонах України є відсутність програм соціально-економічного розвитку в значної кількості територіальних громад (малих міст, селищ, сіл), а отже, недостатня визначеність пріоритетів розвитку таких територій; втручання уряду в роботу приватного бізнесу та значні адміністративні перешкоди для розвитку інвестиційної діяльності; відсутність регіональної системи маркетингу та промоції, недостатня розвиненість інфраструктури підтримки та системи інформаційного забезпечення інвестиційної діяльності; недостатній рівень кадрового потенціалу органів місцевого самоврядування та державної служби, задіяного в інвестиційних процесах на регіональному та місцевому рівнях; військовий конфллікт на сході України. Отже, необхідною передумовою сталого соціально-економічного розвитку в регіонах та забезпечення якісного економічного зростання в державі $є$ висока інвестиційна активність, яка досягається не тільки шляхом збільшення реалізованих інвестиційних ресурсів, але й за рахунок їх ефективного використання у пріоритетних секторах економіки.

Для підвищення інвестиційної привабливості регіонів України необхідно розробити механізм, форми та методи удосконалення регіональної політики у сфері залучення інвестицій, що базуватиметься на засадах поєднання ринкових і владних інструментів і включатиме:

- визначення стратегічних напрямів та пріоритетів інвестиційного розвитку області, прогнозних обсягів потреби регіону в інвестиціях, у тому числі іноземних, на довгострокову перспективу, їх конкретизація на найближчі 5 років з послідуючою деталізацією щорічно;

- конкретизація пріоритетів інвестування, суб'єктів інвестування, розміру інвестицій та соціально-економічних наслідків для території, визначення суб'єктів та механізмів контролю в щорічних програмах соціальноекономічного та культурного розвитку територій;

- опрацювання досвіду, підготовка та надання органам державної влади пропозицій щодо вдосконалення нормативно-правової бази, яка регулює залучення іноземного капіталу та його ефективне використання в господарській діяльності на території України;

- формування конкурентних переваг області у сорері інвестування, в тому числі шляхом підготовки належних бізнес-пропозицій, що враховують як інтереси території, так і інвесторів;

- задіяння інструментів маркетингу регіону під час формування позитивного іміджу області;

- стимулювання залучення іноземних інвестицій в економіку області через використання важелів впливу фіскального та дозвільного характеру;

- формування кадрового потенціалу державної служби, спроможного забезпечити ефективну роботу з іноземними інвесторами;

- конструктивна співпраця органів виконавчої влади та місцевого самоврядування з суб'єктами господарювання територій (державно-приватне партнерство) та об'єднання їх зусиль щодо залучення ефективного інвестора та досягнення бажаного конкретного результаTy; 
- створення інфрраструктурних елементів та удосконалення системи інформаційного забезпечення інвестиційної діяльності;

- моніторинг досягнутих результатів, узагальнення досвіду, корегування прогнозів та програм [5].

Підсумовуючи вищевикладене, створення дієвого механізму регіональної інвестиції політики дозволить подолати диспропорції, що постійно супроводять інвестиційну діяльність підприємств значної кількості територіальних громад (малих міст, селищ, сіл).

\section{ВИСНОВКИ 3 ПРОВЕАЕНОГО АОС ІІАЖЕННЯ І ПЕРСПЕКТИВИ ПОАА ЬШИХ РОЗВІАОК У ЦЬОМУ НАПРЯМ}

Аналіз сучасного стану інвестиційної діяльності підприємств на регіональному рівні дає можливість зробити такі висновки. Серед регіонів найбільше освоєння капітальних інвестицій належить тим, де значна кількість приватних підприємств, наявність промислово розвинутих підприємств металургійного, машинобудівного комплексів, хімічної промисловості та добре розвинута транспортна інфрраструктура.

Наведено головні причини регіональних диспропорцій капіталовкладень інвестицій. Серед них: відсутність програм соціально-економічного розвитку в значної кількості територіальних громад (малих міст, селищ, сіл); відсутність регіональної системи маркетингу та промоції, недостатня розвиненість інфраструктури підтримки та системи інформаційного забезпечення інвестиційної діяльності; недостатній рівень кадрового потенціалу органів місцевого самоврядування та державної служби, задіяного в інвестиційних процесах на регіональному та місцевому рівнях; військовий конфрлікт на сході України.

Розкрито головні напрями підвищення інвестиційної привабливості регіонів України, а саме: визначення стратегічних напрямів та пріоритетів інвестиційного розвитку області; конкретизація переваг інвестування, суб'єктів інвестування, розміру інвестицій та соціально-економічних наслідків для території; опрацювання досвіду, підготовка та надання органам державної влади пропозицій щодо вдосконалення нормативно-правової бази. Обгрунтовано необхідність розроблення механізму, форм та методів удосконалення регіональної політики у сорері залучення інвестицій, що базуватиметься на засадах поєднання ринкових і владних інструментів.

\section{Література:}

1. Державна служба статистики України. URL: http://www.ukrstat.gov.ua (дата звернення 18.10.2019)

2. Котова І.М. Регіональні аспекти розвитку інвестиційного процесу в Україні. URL: http://dspace.oneu.edu.ua/jspui/bitstream / 123456789/2198/1/ \% D0 \% A0\%D0\%B5\% \% D0\%B3\% D1\% $96 \%$ D0 \%BE \% D0 \% BD \% D0 \% B - \% D0 \% BB \% D 1\% 8C \%D0\%BD\%D1\%96\%20\%D0\%B0\%D1\%81\%D0\%BF\%D0\%B5\%D0\%BA\%D1\%82\%D0\%B8\%20\%D1\%80\%D0\%BE\%D0\%B7 \% D0 \% B2 \% D0 \% B 8 \% D $1 \% 82 \%$ D0 \% BA \% D1\%83\%20\%D1\%96\%D0\%BD\%D0\%B2\%D0\%B $5 \%$ D $1 \% 81 \%$ D $1 \% 82 \%$ D $0 \%$ B 8 \% D $1 \%-$
$86 \%$ D $1 \% 96 \%$ D0\% B $9 \%$ DO \% BD \% D0 \% BE \% D0 \%B3\%D0\%BE \% 20\%D0\%BF\%D1\%80\%D0\%BE\%D1\%86\%D0\%B5\%D1\%81\%D1\%83\%20\%D0\%B2\%20\%D $0 \%$ A $3 \%$ D $0 \%$ B A \% D $1 \% 80 \%$ D $0 \%$ B 0 $\%$ D $1 \% 97 \%$ D0\%BD\%D1\%96.Pdf (дата звернення 19.10.2019).

3. Федорчак О. В. Проблеми фрормування основних джерел інвестування в Україні. Теорія та практика державного управління. 2017. 1 (56). С. 1-9.

4. Сімків Л.Є. Стан інвестиційної активності в регіонах України. Економіка і суспільство. 2016. Вип. 2. С. $430-435$.

5. Іртищева І.О., Крамаренко І.С. Інвестиційна привабливість економіки: міжрегіональні асиметрії. Регіональна економіка. 2014. № 2 (72). С.84-95.

6. Крамаренко І.С. Ефективність використання інвестиційного потенціалу національної економіки у контексті впливу на економічне зростання. Вісник ХНАУ. 2019. № 1. С. 403-413.

7. Крамаренко І.С. Інвестиційне забезпечення агропродовольчої сфрери України: сучасний станта перспективи розвитку. Інвестиції: практика та досвід. 2013. № 5. С. $30-33$.

\section{References:}

1. State Statistics Service of Ukraine (2019), available at: http://vvv.ukrstat.gov.ua (Accessed 18 Oct 2019).

2. Kotova, I.M. (2003), "Regional aspects of the development of the investment process in Ukraine", available at: URL: http://dspace.oneu.edu.ua/jspui/ bitstream / $123456789 / 2198 / 1 / \%$ D $0 \%$ A $0 \%$ D $0 \%$ B $5 \%$ \% D \% B 3 \% D $1 \% 96 \%$ D $0 \%-$ BE $\%$ D0 \%BD\%D0\%B0-\%D0\%BB \%D1\%8C\%-D0\%BD\%D1\%96\%20\%D0\%B0\%D1\%81\%D0\%BF\%D0\%B5\%D0\%BA \%D1\%82\%D0\%B8\%20\%D1\%80\%D0\%BE\%D0\%B $7 \%$ D0 \% B2 \% D0 \% B 8 \% D1 \% $82 \%$ D0 \% BA \% D1\%83\%20\%D1\% $96 \%$ D0\%BD\%D0\%B2\%D0\%B $5 \%$ D $1 \% 81 \%$ D $1 \% 82 \%$ D $0 \%$ B $8 \%$ D $1 \%-$ $86 \%$ D $1 \% 96 \%$ D0\% B $9 \%$ D $\%$ BD \% D $\%$ BE \%D0\%B3\% D0\%BE\% 20\%D0\%BF\%D1\% 80\%D0\%BE\%D1\%86\%D0\%B5\%D1\%81\%D1\%83\%20\%D0\%B2\%20\%D $0 \%$ A $3 \%$ D $0 \%$ B A \% D $1 \% 80 \%$ D $0 \%$ B $0-$ $\%$ D1\%97\%D0\%BD\%D1\%96.Pdf (Accessed 10 Oct 2019).

3. Fedorchak, O. V. (2017), "Problems of formation of the main sources of investment in Ukraine", Public administration theory and practice, vol. 1(56), pp. 1-9.

4. Simkiv, L. Ye. (2016), "State of investment activity in the regions of Ukraine. Economy and society", vol. 2, pp. $430-435$

5. Irtyscheva, I.O. and Kramarenko, I.S. (2014), "Investment attractiveness of the economy: inter-regional asymmetries", Regional economy, vol. (72), pp. 84-95.

6. Kramarenko, I.S. (2019), "Efficiency of using the investment potential of the national economy in the context of its impact on economic growth", KhNAU Bulletin, vol.1, pp. 403-413.

7. Kramarenko, I.S. (2013), "Investment support of the agro-food sector of Ukraine: current state and prospects for development", Investment: practice and experience, vol. 5, pp. 30-33.

Стаття надійшла до редакцї̈ 21.10.2019 p. 